\title{
The Earliest Known Surviving Western Medieval Metaphysics Commentary
}

\author{
REGA W OOD \\ Yale U niversity
}

Erfurt Quarto 290 includes two commentaries on Aristotle's M etaphysics. Timothy B. Noone established the attribution to Richard Rufus of Cornwall of the commentary that appears on folios 1-40,1 chiefly on the basis of a thirteenth-century ascription to Richard Rufus, deciphered by Fr. Leonard Boyle; the aim of this essay is to show that the author of the commentary on folios 46-56 is also Richard Rufus. Since the manuscript itself was copied before 1250 , both commentaries are clearly early. Noone calls the commentary on folios 1-40, the Scriptum, but that seems misleading since Noone al so claims that what we have is a record preserved by its auditors, a reportatio ( $p$. $65)$. And in medieval scholarly practice, a reportatio is distinguished from a scriptum, which is a written version corrected by the author and meant for publication. In order not to prejudice the question whether thiscommentary is reportatio or a scriptum, we will call it the Dissertatio in M etaphysicam A ristotelis, taking the term 'Dissertatio' from the work's incipit (Vat. lat. 4538, fol. 1ra): "Placet nobis nunc parumper disserere de quadam propositione quam dicit A ristoteles in 'Veteri Philosophia.'" Rufus cites the Dissertatio as the work of a secular author, ${ }^{2}$ so it must have been written before he became a Franciscan in 1238. The shorter, more primitive commentary found on folios 46-56 probably dates from around 1235, but the basis for that claim will be stated at the end of this paper. Most of this essay is devoted to establishing the attribution of the earlier commentary to Rufus, chiefly on the basis of comparisons with Rufus's Dissertatio in M etaph. and his "De intellectu divino."

Rufus's first M etaphysics commentary, which we will call the M emoriale quaestionum Richari Rufi in M etaphysicam Aristotelis ( Mem.), begins with the words:

Quoniam temporis interruptione brevissima scientia laboriose adquisita ab anima relabitur humana, attestante philosopho quod omnium habere memoriam et in nullo peccare magis est divinae condicionis

1. T. Noone "An Edition and Study of the Scriptum super M etaphysicam, bk. 12, dist. 2," (Ph.D. diss., University of Toronto, 1987).

2. Gál, G., "Commentarius in Metaphysicam Aristoteliscod. Vat. lat. 4538, fons doctrinae Richardi Rufi," Archivum Franciscanum H istoricum 43 (1950) :214-15. 
quam humanae, ne igitur tenebris ignorantiae mens avida, conclusa mole carnis, profundius obfuscetur, sub quarum velamine famosarum maxime quaestionum veritas lateat non investigata, quae per locorum spatia diffuse distenditur amplissima, licet nobis parumper de ipsa disserere, ut ipsius habeatur memoriale.

The text ends with a complete sentence- "Unde licet opposita intelliguntur insimul ab intelligente, non tamen oportet quod sint simul in se extra in re"-though there is no resounding conclusion. A different, much later, hand has continued the text in mid-column, with the words, "Item, sequitur." Whether that sentence is meant to link our commentary to what is now the next column on the next quire is by no means clear, but it seems unlikely that the two texts belong together. The quires on which the commentary appears are unnumbered. The first is complete (eight folios). The second was intended to be only half the usual length (four folios), which indicates that the scribe planned to complete the work about where it now ends. Since the last quire is missing its last leaf, however, we do not know whether the work is complete. It may be incomplete, but if so, little has been lost.

Like Rufus's other early commentaries, the M emoriale is principally comprised of brief questions based on the Aristotelian text or on Averroes' commentary. So brief are most of these questions that only three of the eleven books are more than one folio long. By far the longest is the commentary on its last book, book Lambda.

Transcribed in the fall of 1996 from Erfurt Q 290 f.46ra-55vb, the first reason to attribute this work to Rufus was its presence in the Ave Maria Aristotle quires (Erfurt Q 290 and Q 312),3 which contain other works by Rufus. O nce it was clear that it was a M etaphysics commentary, there was a further reason for the attribution: We know that Rufus wrote two M etaphysics commentaries. In his Dissertatio in M etaph., he refers to a previous Physics commentar ${ }_{1}{ }^{4}$ and the Physics commentary refers in turn to a previous $M$ etaphysics commentary. Consequently, when we had completed the transcription, we checked the Physics reference to Rufus's first M etaphysics commentary, hereafter M em. In Physics IV, Rufus says:

Ulterius intelligendum quod esse mutabile non addit novam naturam super esse simpliciter. Propterea dicimus quod simul debet fieri tractatio de ente primo et ente simpliciter, sicut in Philosophia prima loquor de causato. (Q312.8ra)

This reference led us to look for discussions of caused entities in general, which we found. For example, at the end of book IV, Rufus speaks generally

3. Cf. "Richard Rufus's Speculum animae: Epistemology and the Introduction of Aristotle in the West," in Die Bibliotheca Amploniana im Spannungsfeld von Aristotelismus, Nominalismus und $\mathrm{H}$ umanismus, ed. A. Speer, Miscellanea M ediaevalia 23 (Berlin, 1995), pp. 86-109.

4. R. Wood, "Richard Rufus of Cornwall and Aristotle's Physics," Franciscan Studies 52 (1992):247-81. 
about all caused things, abstracting from whether they are created or generated:

Mem. IV: Quaeritur utrum contradictoria possunt simul esse in eodem. Quod sic videtur, quia ... omne causatum inquantum est ab agente habet esse, inquantum fit ex nihil habet non esse ...

Ad primum dicendum quod esse quod accipitur a causa efficiente destruit non esse, quod vero a causa materiali ponit non esse. Ponit enim non manere causatum de natura propria cum esse quod recepit ab efficiente, et ita patet ad primum....

Et nota quod contradictorie opposita sunt termini generationis et creationis sed differenter . . . ( Q 290.47rb)

In book XI, Rufus tells us that caused things are posterior to their causes, both naturally and temporally: "Primum est notabile quod efficens praecedit cau satum prioritate temporis et naturae...." (Q290.52va). He adds that caused things owe their entity to causes: "Undenon-entitas refertur ad causatum, entitas autem attribuitur cau sae cui praeterita et futura sunt praesentia ... ." (Q 290.55va).

Clearly, the author of the M emoriale does discuss "caused things" in abstraction from particular caused things. So we looked for further evidence that might confirm or disconfirm the attribution-namely, for similarities and dissimilarities with known works by Rufus.

\section{COMPARISON WITH RUFUS'S DISSERTATIO IN METAPH, COMMENTARY}

The obvious place to start was with Rufus's principal M etaphysics commentary, his Dissertatio in M etaph. (Diss.). The two commentaries are divided into the same eleven books, ending with Lambda, and lacking Kappa; the same translation is employed-the "nova" by Michael Scot which accompanies Averroes.

Aristotle is repeatedly named, but seldom referred to as "the Philosopher": indeed, one reference in the early commentary to the "Philosopher" turns out to be a citation of Boethius (VII Q290.49vb). Only twice cited by name, as "Aweroys" or "Averoys," Averroes is commonly called "the Commentator." In discussing Saturn, both commentaries refer to the Greek astronomers Eudoxus and Callippus as "O ditius" and "Kilonius" (Q .290 39ra and $54 \mathrm{ra}) .5$

The statements of purpose with which the works begin employ an unusual turn of phrase "parumper disserere de"-a similarity that is shared with a third work:

Mem. I: . . . licet nobis parumper de ipsa disserere, ut ipsius habeatur memoriale, ... (Q290.46ra)

5. Noone (op. cit. p. 165 and 261) reads Rilonius and notes the irregular spelling. 
Diss. I: Placet nobis nunc parumper disserere de quadam propositione quam dicit Aristoteles in veteri Philosophia (Vat. lat. 4538.1ra)

Contra Averroem (CAv): Liceat nobis parumper disserere de quibusdam verbis ipsius philosophi Averrois... (Q 312.81va)

More important are the shared views. For instance, Rufus defends the claim that there is a plurality of divine ideas, illustrating it with a characteristic example in which God's mind is compared with a corporeal mirror. This simile is employed in a number of Rufus's works, including the two M etaphysics commentaries, as comparison shows:

Mem. XI: . . . Et propterea intelligendo se intelligit omnia relucentia in ipso sicut in speculo. Et exemplum conveniens est ad hoc: si universum in aliquo speculo describeretur, aliquis inspiciendo speculum non solum intelliget speculum, immo etiam universum in ipso descriptum . . . (Q290.54vb)

Diss. XI I.7 q.9: . . . Et ut magis illud intelligamus, ponamus exemplum in rebus corporalibus sic. . . . Ponamus igitur per impossibile quod omnia visibilia per unum idolum sunt visibilia. . . Manifestum est quod si quis aspiceret in illo speculo, diceret se unum solum videre. . . . (N1987.304-305)

Similarly characteristic is Rufus's defense of Plato's views on universals against Aristotle. An important element of this defense is the claim that Aristotle misinterpreted Plato by mistakenly ascribing to him the view that universals existed separately not only without matter, but apart from any soul. Rufus understands Plato to hold only the view that forms can exist as ideas without being individually instantiated in matter, distinct from sensible objects: Rufus says that Aristotle "imposed on Plato" the doctrine of separated forms apart from the soul. According to Rufus, this distortion enabled Aristotle to employ the so-called "third man" argument against Plato, an infinite regress argument which claims that Plato is committed to positing forms of forms:

Mem. VII: Quod non per se extra animam et materiam hoc probat Aristotelem, quia ponere hoc est ponere formas separatas, sicut Aristoteles imponit Platoni. ( Q290.48rb)

Diss. I: Ponit et aliam increpationem, dicens quod Plato perscrutabatur 'de communitate individuorum inter se', et posuit ideas separatas ab istis et nullam naturam esse praedicabilem de ipsis, similiter debuisset facere [ de] eis speciebus, scilicet ponere ideam eis, et similiter aliam in superioribus, et ita ut essent idearum idea et formarum forma. Non autem fecit, et ideo bene solvit. Non enim posuit nisi formas separatas a sensibilibus vel ideas. (Q 290.4vb)

Not Aristotle but Plato understood universals correctly according to Rufus. Properly speaking, the term 'universal' refers to ideas in the mind; it refers only secondarily to the kind of form which combines with matter. The 
disagreement between Aristotle and Plato on universals, Rufus attributes to ambiguity in the use of the term 'universal'. Plato employs it properly to refer to forms in the intellect or ideas; less properly Aristotle refers to forms which exist outside the mind. 6 The difference between the two philosophers is succinctly stated in a discussion of ideas, written after the M emoriale and before the Dissertatio, the first question in Rufus's Contra Averroem.

CAv I: Erit igitur et ipsa forma-natura universale, et in hac acceptatione accipit Aristoteles et sui sequaces hoc nomen 'universale'. Plato autem et sui sequaces hoc nomen 'universale' accipiunt praecise pro formaidea, et non pro forma-natura, et haec videtur contrarietas esse inter hos philosophos... ut mihi videtur omnino limpidius inspexit et strictius secutus est impositionem nominis qui id eae huius nominis impositionem attribuit. ( Q 312.83ra)

In commenting on the M etaphysics, Rufus makes much the same point, echoing the words of the early commentary in the later one.

Mem. VII: Dicendum quod secundum propriam acceptionem huius nominis 'universale' significat universale esse formae quod habet in intellectu, hoc est prout ipsa est species vel similitudo rei. Forma tamen cuius esse vocatur in anima per hoc nomen 'universale' est extra animam et in materia. Unde ipsa est res et intellectus, et ipsa exsistens intellectus est similitudo eiusdem prout est forma rei et inquantum est similitudo.

Unde proprie accipendo hoc nomen 'universale' dicendum est quod non habet esse nisi in anima solum. Quia tamen Aristoteles non solum dicit formam esse universale prout habet esse in anima, sed prout habet esse extra animam, et hoc sive ipsa consideretur inquantum est in multis et non in singulis sive consideretur inquantum est in singulis, ideo potest dici universale habere esse in anima et extra animam. (Q290.48va)

Diss. VII: Ad hoc dicendum quod secundum propriam acceptionem huius nominis 'universale' significat universale esse formae quod habet in intellectu, hoc est prout est species sive similitudo rei. Forma tamen cuius esse notatur in anima per hoc nomen 'universale' est extra animam et in materia. Unde ipsa est res et intellectus, et ipsa exsistens intellectus est similitudo eiusdem prout est forma rei; et in quantum est similitudo significatur per hoc nomen 'universale.'

Unde proprie accipiendo hoc nomen 'universale' dicendum est quod universale non habet esse nisi in anima. Quia tamen Aristoteles dicit formam non solum universale prout habet esse in anima, sed etiam prout habet [esse] extra animam, et hoc sive ipsa consideretur in quantum est in multis sive consideretur in singulis, ideo potest dici

6. For a further discussion of Rufus's Platonism, see "Richard Rufus and the Classical Tradition," in Neoplatonisme et philosophie medievale, ed. L. Benakis, Rencontres de philosophie medievale 6 (Turnhout: Brepols, 1997), pp. 229-51. 
universale habere esse in anima et extra animam, et sive sit commune multis sive praedicabile de singulis. (Q290.21va)

This theory of universals, and the defense of Plato it includes, is not espoused by any author other than Rufus to the best of our knowledge.

Less distinctive, as far as we know, are Rufus's views on names. Oddly enough, both M etaphysics commentaries include a gloss on Priscian's view that names signify substance and quality. Moreover, as in the discussion of universals, the Dissertatio quotes from the M emoriale. The questions begin in the same way:

Mem. VIII: Quaeritur an omne nomen significet substantiam cum qualitate, sicut dicitur an non.

Et videtur quod non:

Nam si sic, hoc nomen 'homo' cum sit nomen significat substantiam cum qualitate. Vocetur illa substantia A et vocetur qualitas B. A est nomen, ergo significat substantiam cum qualitate; nominetur illa qualitas $C$ et convenit procedere ut prius, et sic in infinitum. (Q290.49vb)

Diss. VIII: Sed potest quaeri quid signficet nomen, et si substantiam cum qualitate, ut vult Priscianus quaeratur utrum omne nomen significet substantiam cum qualitate, et quid appellatur substantia et quid qualitas cum dicitur nomen significare substantiam cum qualitate.

Et videtur quod non omne nomen significet substantiam cum qualitate...

Nam si sic, ergo hoc nomen 'homo' significat substantiam cum qualitate. Nominetur illa qualitas nomine $A$ et substantia nomine B. A est nomen, ergo significat substantiam cum qualitate; nominetur illa qualitas nomine $C$, et procedatur sicut prius, et erit processus in infinitum. (Q.29023vb)

They both reject the same opinion:

Mem. VIII: Dicunt quidam quod cum dicitur nomen significare substantiam cum qualitate quod illa substantia est quoddam aggregatum ex forma speciei et substantia materiae; forma autem speciei dicitur qualitas, et substantia contrahitur a materia sive a genere quod est loco materiae.

Sed ista solutio non habet locum nisi in nominibus significantibus substantiam compositam, ut hoc nomen 'homo'. Unde adhuc remanet haec quaestio solvenda in nominibus dicentibus substantiam simplicem ut hoc nomen 'lux', quoniam difficile est in talibus diversitatem substantiae et qualitatis apprehendere. (Q290.49vb)

Diss. VIII: Et si quis dicat quod cum dicitur "nomen significare substantiam," illa substantia est aggregatum ex forma speciei et substantia materiei. Forma autem speciei dicitur qualitas, et hoc manifeste patet in hoc nomine 'homo.' ... .

Sed haec solutio non habet locum nisi in nominibus significantibus 
substantiam compositam. Unde adhuc remanet quaestio solvenda in nominibus significantibus substantiam simplicem, ut in hoc nomine 'nix'. Quid igitur appellatur qualitas, et quid substantia? (Q 290.23vb)

But the later commentary, the Dissertatio, also rejects the solution tentatively advanced in the early commentary.

Mem. VIII: Dici tamen potest quod eadem est substantia et qualitas in huius nominibus secundum rem, diversa tamen secundum rationem. Dicitur enim significare substantiam inquantum habet naturam subiciendi, qualitatem vero inquantum habet naturam praedicandi. Verbi gratia: sit A nomen simplex, si dicam A est A, idem est quod subicitur et quod praedicatur, tamen signficatum huius nominis $A$ prout subicitur est substantia, prout praedicatur est qualitas. Sic igitur in omnibus nominibus tam simplicibus quam compositis est invenire substantiam et qualitatem. (Q290.49vb)

Diss. VIII: Ad hoc autem potest quis respondere quod in aliquibus nominibus, utpote in illis quae significat substantiam compositam, secundum rem differunt substantia et qualitas, in aliquibus non differunt secundum rem sed solum secundum modum. Ens enim et esse idem sunt secundum rem, sed differunt secundum modum in nominibus. ... Sed illud dicitur substantia inquantum habet naturam subiciendi et qualitas inquantum habet naturam praedicandi. Verbi gratia: sit A nomen simplex. Si dicam "A est A," idem est quod subicitur et quod praedicatur, tamen significatum huius nominis A prout subicitur est substantia, prout autem praedicatur est qualitas. Sic igitur in omnibus nominibus, tam simplicibus quam compositis, est invenire substantiam et qualitatem.

Sed contra: ista est diversitas quae est secundum modum et quae invenitur in significato nominis simplicis, aut solum causatur ab intellectu nostro aut isti diversitati correspondet aliqua diversitas in re extra animam ... (Q290.23vb-24ra)

\section{COMPARISON WITH “DE INTELLECTU DIVINO”}

In the course of comparing the two M etaphysics commentaries, we have already seen similarities with a number of other works-chiefly, with the intermediate Contra Averroem. Although we cannot make comparisons with every other work, we must consider one other work: Rufus's "De intellectu divino" (IDiv). Though it is a minor work, like the Dissertatio, it is explicitly ascribed to Rufus by a thirteenth-century hand in the manuscript where it is preser ved, Assisi Bibl. Com. 138.7 Since it is so short, there are comparatively few

7. Doucet, V., Prolegomena, in Summa H alesiana IV p.1, Quaracchi 1948, Typographia Collegii S. Bonaventurae, p. 141. 
points of comparison, but three similaritiesin doctrine can be adduced. First, both works teach that the First Cause knows everything by knowing itself. Contrary to the opinion Rufus was to defend later,8 they follow Averroes and deny that the First Cause knows others, and they argue for that position by pointing to the dissimilarities between our knowledge and that of the First Cause: We know passively and by reception; not so, the First Cause.

IDiv: Ad ista potest probabiliter responderi quod istud nobile primum nihil extra se intelligendo, se intelligens omnia verissime intelligit. Et hoc, ut dicunt quidam, intelligit Aristoteles probare in prima parte illius capituli, Scientia autem patrum (12.8.1074b13). Nec addit forte secundum rem hic quod intelligit omnia et quod se intelligit. . . . Ideo addendum [ est] quod ipse intelligit non per receptionem, quia nullius speciem vel formam recipit, cum non sit receptivum, cum omne receptivum sit in potentia. $\mathrm{Nec}$ se ipsum intelligit recipiendo, cum sit ipse actus purus . . . diversificet suam cognitionem a nostra, scilicet cognoscere non per receptionem. (A138.262vb)

Mem. XI: Aliter dicitur sic: quod Primum tantum intelligit se ipsum, et tamen intelligendo se ipsum intelligit omnia, quia in ipso relucent omnia sicut in speculo.

Ratio Aristotelis quae probat quod Primum non intelligit alia a se per receptionem est ista: si intelligeret alia a se, perficeretur per per ea-quod est inconveniens. Sic enim intelligit intellectus noster, scilicet per receptionem, et ideo per recepta perficitur. Non contingit autem de intellectu Primi, quia non intelligit per receptionem sed per se ipsum. (Q290.54vb-55ra)

Another fairly common position defended in both works is that the First Cause knows matter by privation:

IDiv: Et dici potest quod sicut intelligimus materiam per privationem formae, sic et ipse per privationem similiter. (A138.262vb)

Mem. XI: Et ideo potest dici quod materia prima magis cognoscitur per privationem sive per modum privationis quam per modum positionis. Et ideo si intelligeretur, intelligeretur per ideam privationis quam non est ponere in Primo. Unde potest dici quod Primum cognoscit primam materiam, non tamen per ideam suam in ipso exsistentem, sed per cognitionem positionis formae cognoscit materiam primam. Et consimiliter est dicere de omnibus privationibus quod cognoscuntur cognitis suis habitibus. ( $Q 290.55 \mathrm{rb}$ )

As is clear, however, the treatment in the early M etaphysics commentary is more qualified and more sophisticated: We cannot exactly say that the First

8. R. Wood, "Distinct Ideas and Perfect Solicitude: Alexander of Hales, Richard Rufus, and Odo Rigaldus." Franciscan Studies 53 (1993): 7-46./ m no. 9 Gál, G. "Opiniones Richardi Rufi a censore reprobatae," Franciscan Studies 35 (1975) :136-93. 
Cause knows by privation, since privation is not to be posited in the First Cause. So we say instead that in so far as matter is privation, it is known by knowing the corresponding habit. The two works suggest the same strategy: understanding an absence by knowing something present. But the second shows more theological sophistication.

Rufus on enuntiables presents a similar case. The doctrine is similar: In "De intellectu divino," Rufus holds that enuntiables about God are true from eternity, but since they are relations that have no existence apart from their extremes, we need not posit more than one eternal being. In commenting on the M etaphysics, however, Rufus defends a more general conclusion to cover other eternal truths-for example, that triangles have three sides: From the fact that many enuntiables are true from eternity, it does not follow that there are a plurality of beings, since God's knowledge does not depend on beings.

IDiv: Item, qualiter enuntiabilia sint ab aeterno, ut Deum-esse et Deumesse-esse-verum. Videtur mihi quod enuntiabilia non dicit aliquid sed solummodo relationem extremorum. Unde Deumesse non est alia essentia a Deo. (A138.262vb)

Mem. XI: Dicendum quod non sunt plura ab aeterno, et tamen sunt plura enuntiabilia ab aeterno vera. $\mathrm{Nec}$ tenet hoc argumentum: enuntiabilia plura sunt vera ab aeterno, ergo sunt ab aeterno. (Q 290.48rb)

We know that Rufus did not abandon the position on relations held in "De intellectu divino." As Gedeon Gál pointed out, in his last known work, the Paris Commentar $y,{ }^{9}$ Rufus held that relations do not signify anything apart from the relata. Still the IDiv position does not explain why truths unrelated to God do not require that we posit eternal beings other than God. Perhaps that is why he revised his view. At any rate, in the later Dissertatio, Rufus adopts the position of the Memoriale, which he repeats word for word:

Mem. VII: Dicendum quod non sunt plura ab aeterno, et tamen sunt plura enuntiabilia $a b$ aeterno vera. $\mathrm{Nec}$ tenet hoc argumentum: enuntiabilia plura sunt vera ab aeterno, ergo sunt ab aeterno.

Ad argumentum in oppositum dicendum quod verum quoddam cadit in cognitione nostra, et illud verum cadit sub ente et ad ipsum sequitur. Et si accipiatur hoc modo verum, non est haec propositio vera: 'Enuntiabilia sunt ab aeterno vera'. Est autem aliud verum quod cadit in cognitione primae causae, et istud verum non est sub ente, nec ad illud verum sequitur ens, et illo modo veri sunt enuntiabilia vera $a b$ aeterno, nec ex hoc sequitur quod sint ab aeterno. (Q 290.48rb)

9. Gál, G. "Opiniones Richardi Rufi a censore reprobatae," Franciscan Studies 35 ( 1975$): 136-93$. 
Diss. VII: Ad aliud dicendum quod non sunt plura ab aeterno, et tamen sunt plura enuntiabilia vera ab aeterno. $\mathrm{Nec}$ tenet hoc argumentum: enuntiabilia sunt vera ab aeterno, ergo sunt ab aeterno.

Ad argumentum in oppositum, dicendum quod verum quoddam cadit in cognitione nostra, et illud verum cadit sub ente, et ad ipsum sequitur ens. Et si accipitur hoc modo 'verum', non est haec propositio vera: Enuntiabilia sunt vera ab aeterno. Est autem aliud verum quod cadit in cognitione primae causae, et illud verum non est sub ente nec ad illud verum sequitur ens, et illo modo sunt enuntiabilia vera ab aeterno, nec ex hoc sequitur quod sint ab aeterno. (Vat. lat. 4538.51rb-va)

\section{ATTRIBUTION TO RICHARD RUFUS}

While more similarities could be adduced, these should suffice. The evidence for the authenticity of the early M etaphysics commentary is overwhelming: It appears in a Rufus manuscript. It contains passages that are repeated word for word in a work explicitly ascribed to Rufus in the thirteenth century, Rufus's Dissertatio in M etaphysicam A ristotelis. It defends many of the views Rufus held, including several defended by no other author as far as we know. Moreover, it shares important stylistic similarities with other works by Rufus.

\section{DATING}

$\mathrm{H}$ aving established the attribution of the early $M$ etaphysics commentary to Rufus, we should say a little more about its date. The most important result of the foregoing discussion in that regard comes from the comparison with "De intellectu divino." Both the greater sophistication of the early M etaphysics commentary and its closer resemblance to the Dissertatio suggests that it was not Rufus's first work. The magistral question, "De intellectu divino" preceded it. And as we knew at the outset, the Physics Commentary came later. So we know something about the relative chronology. The order is: "De intellectu divino," M emoriale, "In Physicam Aristot.," Dissertatio.

The absolute chronology is more elusive, however. The main dating tool we have is Rufus's quotation of the Dissertatio in M etaph. A ristot. as the work of a secular author, meaning it is a work produced before the spring of 1238 , when Rufus became a Franciscan. So the date of the Dissertatio is probably around 1237. If we allow a couple years for other works, we may suppose that the M emoriale was not produced before 1235 . If we also assume that Rufus did not follow the example of the Parisian masters who began teaching the libri naturales in 1231 before the commission to expurgate 
them had been appointed, 10 then the likelihood is that it is probably closer to 1235 than 1231.

Thus the newly discovered commentary is at least two years earlier, perhaps as much as sixteen years earlier, than Roger Bacon's M etaphysics commentaries, which were produced some time between 1237 and 1247.11 Taking the date usually assigned, 1245,12 the newly discovered commentary is at least a decade earlier than Bacon's. Produced quite early in his teaching career at Paris, 13 Bacon's commentaries on the M etaphysics are the only other surviving commentaries that may have been produced before 1240 . By contrast, Adam Buckfield's commentary must have been written after 1243 and is usually dated about 1250.14 So Rufus's newly discovered commentary on Aristotle's M etaphysics is the first surviving Western medieval commentary of which we know. 15 It is the earliest evidence we have on how Aristotelian metaphysics was taught at the medieval University.

10. H. Denifle and A. Chatelain, Chartularium Univ. Paris. n. 86 (Paris, 1889), $\mathrm{I}: 143$.

11. J. H ackett, "Scientifia Experimentalis: From Robert Grosseteste to Roger Bacon," in Robert Grosseteste: N ew Perspectives, ed. J. McEvoy, (Steenbrugis, 1995), p. 95.

12. A. Zimmermann, "Some Aspects of the Reception of Aristotle's Physics and M etaphysics in the Thirteenth Century," in Ad litteram, ed. M. Jordan and K. Emery, (Notre Dame, Ind.: 1992), p. 220.

13. Bacon, Quaestiones su pra libros octo Physicorum A ristot., ed. F. Delorme and R. Steele, Opera hactenus inedita Rogeri Baconi 13 (Oxford: Oxford University Press, 1935), p. xxx.

14. A. Maurer, "Adam of Buckfield, Sententia super secundum M etaph., in Nine M ediaeval Thinkers, ed. J. Reginald O'Donnell, C.S.B. (Toronto: Pontifical Institute of Mediaeval Studies, 1955), p. 99.

15. For indications that Aristotle's M etaphysics was taught earlier, cf. A. Gabriel, "M etaphysics in the Curriculum of Mediaeval U niversities," in Garlandia (Frankfurt a. M.: Josef Knecht, 1969), pp. 201-9. 
